\title{
Application of Proton Conductors to Hydrogen Monitoring for Liquid Metal and Molten Salt Systems*
}

\author{
Masatoshi KONDO**, Takeo MUROGA**, \\ Koji KATAHIRA*** and Tomoko OSHIMA*** \\ ${ }^{* *}$ Fusion Engineering Research Center, \\ National Institute for Fusion Science \\ Oroshi 322-6, Toki, Gifu 502-5292, Japan \\ E-mail: kondo.masatoshi@nifs.ac.jp \\ *** TYK corporation, Functional Material R\&D Center, \\ Obata, Tajimi, 507-8607, Japan
}

\begin{abstract}
The chemical control of impurity such as hydrogen and oxygen in coolants is one of the critical issues for the development of liquid metal cooled fast reactors and self-cooled liquid breeder blankets for fusion reactors. Especially, hydrogen (isotopes) level is the key parameter for corrosion and mechanical properties of the in-reactor components. For fission reactors, the monitor of hydrogen level in the melt is important for safety operation. The control of tritium is essential for the tritium breeding performance of the fusion reactors. Therefore, on-line hydrogen sensing is a key technology for these systems. In the present study, conceptual design for the on-line hydrogen sensor to be used in liquid sodium $(\mathrm{Na})$, lead $(\mathrm{Pb})$, lead-bismuth ( $\mathrm{Pb}-\mathrm{Bi})$, lithium ( $\mathrm{Li})$, lead-lithium $(\mathrm{Pb}-17 \mathrm{Li})$ and molten salt $\mathrm{LiF}-\mathrm{BeF}_{2}$ (Flibe) was performed. The cell of hydrogen sensor is made of a solid electrolyte. The solid electrolyte proposed in this study is the $\mathrm{CaZrO}_{3}$-based ceramics, which is well-known as proton conducting ceramics. In this concept, the cell is immersed into the melt which is containing the hydrogen at the activity of $\mathrm{P}_{\mathrm{H} 1}$ of ambient atmosphere. Then, the cell is filled with $\mathrm{Ar}-\mathrm{H}_{2}$ mixture gas at regulated hydrogen activity of $\mathrm{P}_{\mathrm{H} 2}$. The electromotive force (EMF) is obtained by the proton conduction in the electro chemical system expressed as $\mathrm{Pt}, \operatorname{Melt}\left(\mathrm{P}_{\mathrm{H} 1}\right) \mid$ Proton conductor $\mid \mathrm{P}_{\mathrm{H} 2}$, Pt. The Nernst equation is used for the evaluation of the hydrogen activity from the obtained EMF. The evaluations of expected performance of the sensor in liquid $\mathrm{Na}, \mathrm{Pb}, \mathrm{Pb}-\mathrm{Bi}, \mathrm{Pb}-17 \mathrm{Li}, \mathrm{Li}$ and Flibe were carried out by means of the measurement test in gas atmosphere at hydrogen activities equivalent to those for the melts in the reactor conditions. In the test, the hydrogen activity in the gas varied from $2.2 \times 10^{-14}$ to 1 . The sensor exhibited good response, stability and reproducibility.
\end{abstract}

Key words: Hydrogen Sensor, Proton Conductor, Liquid Metal, Molten Salt, Fast Reactor, Fusion Reactor

\section{Introduction}

The application of liquid metals or molten salts is essential for the development of innovative fission and fusion reactors. The liquid metals of sodium $(\mathrm{Na})$, lead $(\mathrm{Pb})$ and lead-bismuth $(\mathrm{Pb}-\mathrm{Bi})$ are the coolant of fast reactors $(\mathrm{FRs})^{(1)(2)}$. The lithium $(\mathrm{Li})$, lead-lithium $(\mathrm{Pb}-17 \mathrm{Li})$ and molten salt $\mathrm{LiF}-\mathrm{BeF}_{2}$ (Flibe) are the promising materials as a coolant and a tritium breeding material of fusion reactor ${ }^{(3)(4)(5)}$.

One of the critical issues in the Na cooled FRs is chemical aspects of sodium/water combustion $^{(6)}$. Even the slight leak of high pressure water/steam into the liquid $\mathrm{Na}$ in a heat exchanger of the reactor can cause a heat and the products of $\mathrm{NaOH}$, which is corrosive to the tube inner wall. Then, hydrogen is generated according to the reaction. If the increase of 
the hydrogen concentration in the liquid $\mathrm{Na}$ is monitored, the leak of the water/steam into the melt can be detected.

As for the lead alloy coolant system, the control of the oxygen concentration is essential to minimize the corrosion of steels. The oxygen potential in the melt can be controlled adequately by using lead oxide $(\mathrm{PbO})$ particles ${ }^{(7)}$ to suppress oxidation corrosion and a liquid metal corrosion ${ }^{(8)(9)}$. The formation of huge amount of $\mathrm{PbO}$ needs to be avoided since this causes the loop plugging. The injection of hydrogen and steam gas mixture into the melt is one of the means to control the $\mathrm{PbO}$ formation ${ }^{(10)}$. Then, the hydrogen level should be checked before and after the $\mathrm{PbO}$ reduction by the online sensor.

In the liquid $\mathrm{Li}, \mathrm{Pb}-17 \mathrm{Li}$ and Flibe, the development of on-line measurement system of tritium in the melt is quite important for the evaluation of tritium release and recovery. The technology for the tritium recovery from $\mathrm{Li}$ using yttrium bed has been progressed ${ }^{(11)}$. However, the on-line sensor, which can detect the change of tritium concentration before and after the recovery, is not developed so far. In the liquid $\mathrm{Pb}-17 \mathrm{Li}$ and Flibe system, the tritium can permeate without the permeation barrier. The online sensor which can detect the change of the tritium concentration by the tritium permeation through the defect of the barrier should be developed.

For these purposes, the development of the on-line hydrogen sensor is quite valuable. The investigation on the solid electrolyte type hydrogen sensor for the high temperature liquid metals and molten salt was performed in the present study. Conceptual design for the on-line hydrogen sensor to be used in liquid metals and molten salt was performed. The evaluation of expected performance of the sensor in $\mathrm{Na}, \mathrm{Pb}, \mathrm{Pb}-\mathrm{Bi}, \mathrm{Pb}-17 \mathrm{Li}, \mathrm{Li}$ and Flibe and experimental validation at hydrogen pressures equivalent to those for the melts in the reactor conditions were carried out.

\section{Theoretical Basis for Hydrogen Measurement in Liquid Metal and Molten} Salt

The solid electrolyte sensor used in the present study is $\mathrm{CaZrO}_{3}$-based ceramics, which is well-known as perovskite-type proton conducting ceramics ${ }^{(12)}$. In perovskite-type proton conductors, electrical carriers are positive holes, excess electrons, oxide ion vacancies and interstitial protons which interact with oxide ions.

To use the perovskite-type proton conducting ceramic as hydrogen sensor, the oxygen activity in measurement gas or liquid is key parameter to keep hydrogen conduction domain. The activity of gas species $\mathrm{X}, \mathrm{Px}$, is represented by the ratio of partial pressure of $\mathrm{X}$ to the standard pressure $\mathrm{P}(=101325 \mathrm{~Pa})$. The required oxygen activity of $\mathrm{P}_{\mathrm{O} 2}$ in case of indium (In) doped $\mathrm{CaZrO}_{3}$ sensor is reported by Kurita et al. ${ }^{(13)}$. For example, the oxygen activity more than $10^{-77}$ is required in the measurement of the hydrogen at the temperature of $400^{\circ} \mathrm{C}$. Thus, the oxygen activity in the liquid $\mathrm{Pb}, \mathrm{Pb}-\mathrm{Bi}, \mathrm{Na}$ and $\mathrm{Li}$ was calculated. The reliable data for the oxygen in $\mathrm{Pb}-17 \mathrm{Li}$ and Flibe could not be found. The oxygen activity of the $\mathrm{Pb}-17 \mathrm{Li}$ may be closed to those of $\mathrm{Pb}$ and $\mathrm{Pb}-\mathrm{Bi}$, since the activity of $\mathrm{Li}$ in $\mathrm{Pb}-17 \mathrm{Li}$ is so small.

The metal oxide formation in the melt and molten salt is considered as the equation of

$$
\frac{\mathrm{x}}{\mathrm{y}} \mathrm{M}+\frac{1}{2} \mathrm{O}_{2}=\frac{1}{\mathrm{y}} \mathrm{M}_{\mathrm{x}} \mathrm{O}_{\mathrm{y}}
$$

and $\mathrm{P}_{\mathrm{O} 2}$ is calculated according to the equilibrium equation of

$$
\mathrm{K}=\frac{(\mathrm{Co} / \mathrm{Cs}, \mathrm{o})^{\frac{1}{\mathrm{y}}}}{\mathrm{P}_{\mathrm{O} 2}^{\frac{1}{2}}}=\exp \left(-\frac{\frac{1}{\mathrm{y}} \Delta \mathrm{G}_{\mathrm{M}_{\mathrm{x}} \mathrm{O}_{\mathrm{y}}}}{\mathrm{RT}}\right)
$$

where $\mathrm{K}$ is equilibrium constant, $\mathrm{Co}$ is oxygen concentration in the melt, $\mathrm{Cs}, \mathrm{O}$ is the solubility of the oxygen in the melt, $\mathrm{R}$ is the gas constant, $\Delta \mathrm{G}$ is the Gibbs free energy for standard formation of metal oxide and $\mathrm{T}$ is the measurement temperature with the unit of $K$.

Figure 1 shows estimated $\mathrm{P}_{\mathrm{O} 2}$ in liquid metals. The dotted lines show the $\mathrm{P}_{\mathrm{O} 2}$ of oxygen in operation conditions. The solid lines show those for their oxides formation conditions.

In the liquid $\mathrm{Pb}$ and $\mathrm{Pb}-\mathrm{Bi}$, the oxygen is controlled using the $\mathrm{PbO}$ particles ${ }^{(7)(14)}$. Then, the oxygen in the melt is controlled at the oxygen saturation conditions at $250^{\circ} \mathrm{C}$. The 
oxygen activity is controlled around $10^{-33}$. This is sufficient for the hydrogen measurement by using In doped $\mathrm{CaZrO}_{3}$ ceramics, and the sensor cell can be directly immersed in the melt. As for the liquid $\mathrm{Na}, \mathrm{Li}$ and Flibe, the activity of oxygen is so low that the hydrogen can not be measured by the direct immersion of the sensor cell.

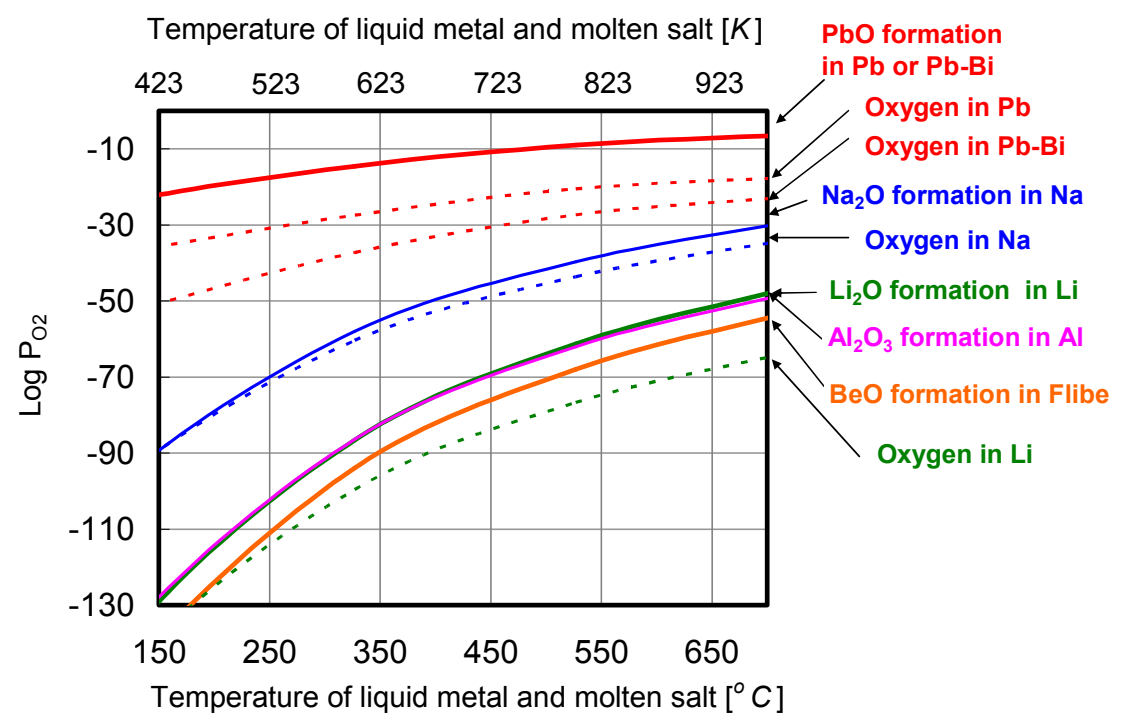

Fig. 1 Oxygen activity $\left(\mathrm{P}_{\mathrm{O} 2}\right)$ of ambient atmosphere in liquid metals and molten salt

\section{Sensor Structure}

The hydrogen sensor for liquid $\mathrm{Pb}, \mathrm{Pb}-\mathrm{Bi}$ and $\mathrm{Pb}-17 \mathrm{Li}$ is shown in Fig.2 (a). The solid electrolyte is directly immersed in the melt, and open circuit consists of metal wire, liquid metal, solid electrolyte, Pt electrode, metal wire and an electrometer with high impedance.

The cell was immersed in the melt which contained hydrogen as the hydrogen activity of $\mathrm{P}_{\mathrm{H} 1}$. In the sensor cell, reference gas is continuously injected and the hydrogen activity is regulated at $\mathrm{P}_{\mathrm{H} 2}$. Then, the system of sensor is expressed as

$$
\mathrm{Pt} \text {, Melt }\left(\mathrm{P}_{\mathrm{H} 1}\right) \mid \text { Proton conductor } \mid \mathrm{P}_{\mathrm{H} 2}, \mathrm{Pt}
$$

In this system, an electromotive force (EMF) is given as

$$
\mathrm{E}=\frac{\mathrm{RT}}{2 \mathrm{~F}} \ln \frac{\mathrm{P}_{\mathrm{H} 1}}{\mathrm{P}_{\mathrm{H} 2}}
$$

where $\mathrm{E}$ is EMF with the unit of $V$ and $\mathrm{F}$ is the Faraday constant.

Figure 2 (b) shows the sensor for liquid $\mathrm{Na}, \mathrm{Li}$ and Flibe. The design of this sensor was based on the sensor study, which was performed for the measurement of hydrogen in liquid $\mathrm{Al}^{(15)}$. The sensor is cap type sensor, which has a gas compartment. The surface of the sensor cell was covered by $\mathrm{Pt}$, and this works as electrode. When the sensor cell is immersed into the melt, sensing part does not wet by the melt due to this gas compartment. This is an advantage for the use in corrosive and reducible melt such as Flibe, Li and $\mathrm{Pb}-17 \mathrm{Li}$. In the gas compartment, a porous oxide of $\mathrm{CaZrO}_{3}$ was filled. This keeps $\mathrm{P}_{\mathrm{O} 2}$ in the gas compartment sufficiently high. This is important to keep the performance of the proton conducting materials.

Hydrogen comes to the compartment from the melt. After equilibration, the hydrogen concentration is derived by the activity of the hydrogen in the compartment $\mathrm{P}_{\mathrm{H} 1}$ according to the Sieverts' law;

$$
\mathrm{S}=\mathrm{k} \sqrt{\mathrm{P}_{\mathrm{H} 1}}
$$


where $\mathrm{S}$ is the hydrogen concentration in the melt with the unit of wppm and $\mathrm{k}$ is the Sieverts' constant.

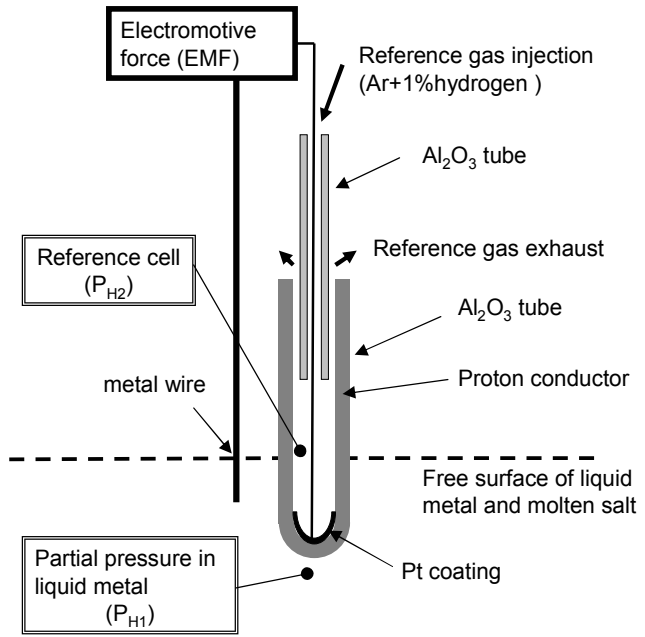

(a)

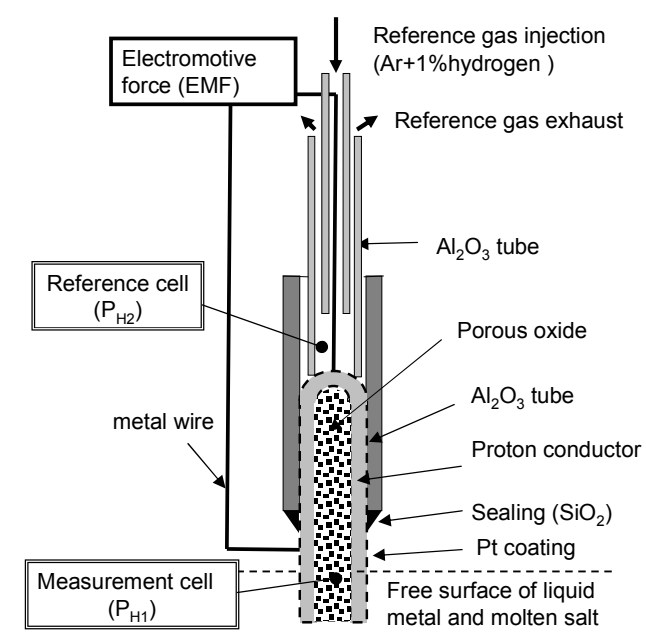

(b)

Fig. 2 Structure of hydrogen sensor (a) direct immersion type sensor for liquid $\mathrm{Pb}, \mathrm{Pb}-\mathrm{Bi}$ and $\mathrm{Pb}-17 \mathrm{Li}$ (b) cap type sensor for liquid $\mathrm{Na}, \mathrm{Li}$ and Flibe

\section{Sensor Performance Test}

\subsection{Test conditions}

The evaluation of expected performance of the sensor at hydrogen activities equivalent to those for the liquid metals and molten salt was carried out in gas atmosphere. Table 1 shows the hydrogen concentration and activity in the melt.

Figure 3 shows the schematic of the experimental apparatus. The sensor made of $\mathrm{CaZr}_{0.9} \mathrm{In}_{0.1} \mathrm{O}_{3-\alpha}$ ceramics was set up in the crucible with $\mathrm{Ar}-\mathrm{H}_{2}$ gas mixture. The sensor electrode was Pt.

Table 1 Hydrogen (isotopes) concentration and activities in liquid metals and molten salt

\begin{tabular}{|c|c|c|c|c|}
\hline & $\begin{array}{l}\text { Concentration } \\
\text { in melt } \\
(\text { wppm }) \\
\end{array}$ & $\begin{array}{l}\text { Sievert's } \\
\text { coefficient } \\
\text { (estimation) }\end{array}$ & $\begin{array}{l}\text { Activity in } \\
\text { melt }\end{array}$ & $\begin{array}{l}\text { Referred } \\
\text { journals }\end{array}$ \\
\hline $\begin{array}{l}\mathrm{Na} \\
\left(500^{\circ} \mathrm{C}\right)\end{array}$ & $4 \times 10^{-5}$ & $157( \pm 19)$ & $6.41 \times 10^{-15}$ & (16) \\
\hline $\begin{array}{l}\mathrm{Pb}-17 \mathrm{Li} \\
\left(500^{\circ} \mathrm{C}\right)\end{array}$ & $1.4 \times 10^{-4}$ & $5.60 \times 10^{3}$ & $2.76 \times 10^{-4}$ & \multirow{2}{*}{ (17) } \\
\hline $\begin{array}{l}\mathrm{Li} \\
\left(500^{\circ} \mathrm{C}\right)\end{array}$ & $4.3 \times 10^{-1}$ & $1.27 \times 10^{13}$ & $3.36 \times 10^{-14}$ & \\
\hline $\begin{array}{l}\text { Flibe } \\
\left(500^{\circ} \mathrm{C}\right)\end{array}$ & $5 \times 10^{-4}$ & 0.05 & $9.87 \times 10^{-3}$ & (4) \\
\hline
\end{tabular}

The activity of the hydrogen in the crucible was controlled by the injection of the gases with different hydrogen activity. The test temperature was $600^{\circ} \mathrm{C}$. The reference gas and measurement gas were continuously injected at the flow rate of $50 c c$ and $100 c c$ per minutes, respectively. $\mathrm{Ar}+1 \% \mathrm{H}_{2}$ gas was used as the reference gas in the sensor cell.

For the test at high hydrogen activity, the Ar+0.5\% hydorgen gas (hydrogen activity of $\left.5 \times 10^{-3}\right)$, Ar+1\%hydorgen gas $\left(1 \times 10^{-2}\right)$, Ar $+10 \%$ hydorgen gas $\left(1 \times 10^{-1}\right)$ or $100 \%$ hydrogen 
gas (1) were used. For the test at low hydrogen activity, Air and oxygen were used after the bubbling in the water at $15^{\circ} \mathrm{C}$ for the estimation of hydrogen activity. The air and oxygen contain moisture as

$$
\mathrm{H}_{2}+\frac{1}{2} \mathrm{O}_{2} \rightarrow \mathrm{H}_{2} \mathrm{O}
$$

Then, the equilibrium constant $\mathrm{K}$ is obtained as

$$
\mathrm{K}=\frac{\mathrm{P}_{\mathrm{H} 2 \mathrm{O}}}{\mathrm{P}_{\mathrm{H} 2} \mathrm{P}_{\mathrm{O} 2}^{\frac{1}{2}}}
$$

where the $\mathrm{P}_{\mathrm{H} 2 \mathrm{O}}$ at $15^{\circ} \mathrm{C}$ is known as $0.01918^{(18)}$, and $\mathrm{P}_{\mathrm{O} 2}$ in the air and oxygen used in the present work is also known as 0.2 and 0.99 , respectively. The equilibrium constant $\mathrm{K}$ is drawn by Gibbs standard free energy of $\mathrm{H}_{2} \mathrm{O}$ formation as;

$$
\mathrm{K}=\exp \left(\frac{-\Delta \mathrm{G}_{\mathrm{H} 2 \mathrm{O}}^{\mathrm{O}}}{\mathrm{RT}}\right)
$$

Then, the combine of eqs. (7) and (8) leads to

$$
\mathrm{P}_{\mathrm{H} 2}=\frac{\mathrm{P}_{\mathrm{H} 2 \mathrm{O}}}{\mathrm{P}_{\mathrm{O} 2}^{\frac{1}{2}}} \exp \left(\frac{\Delta \mathrm{G}_{\mathrm{H} 2 \mathrm{O}}^{0}}{\mathrm{RT}}\right)
$$

The hydrogen activity in the air and oxygen after bubbling in water at $15^{\circ} \mathrm{C}$ were estimated as $4.9 \times 10^{-14}$ and $2.2 \times 10^{-14}$, respectively. This is low enough to simulate the hydrogen activity in the $\mathrm{Na}, \mathrm{Li}, \mathrm{Li}-\mathrm{Pb}$ and Flibe.

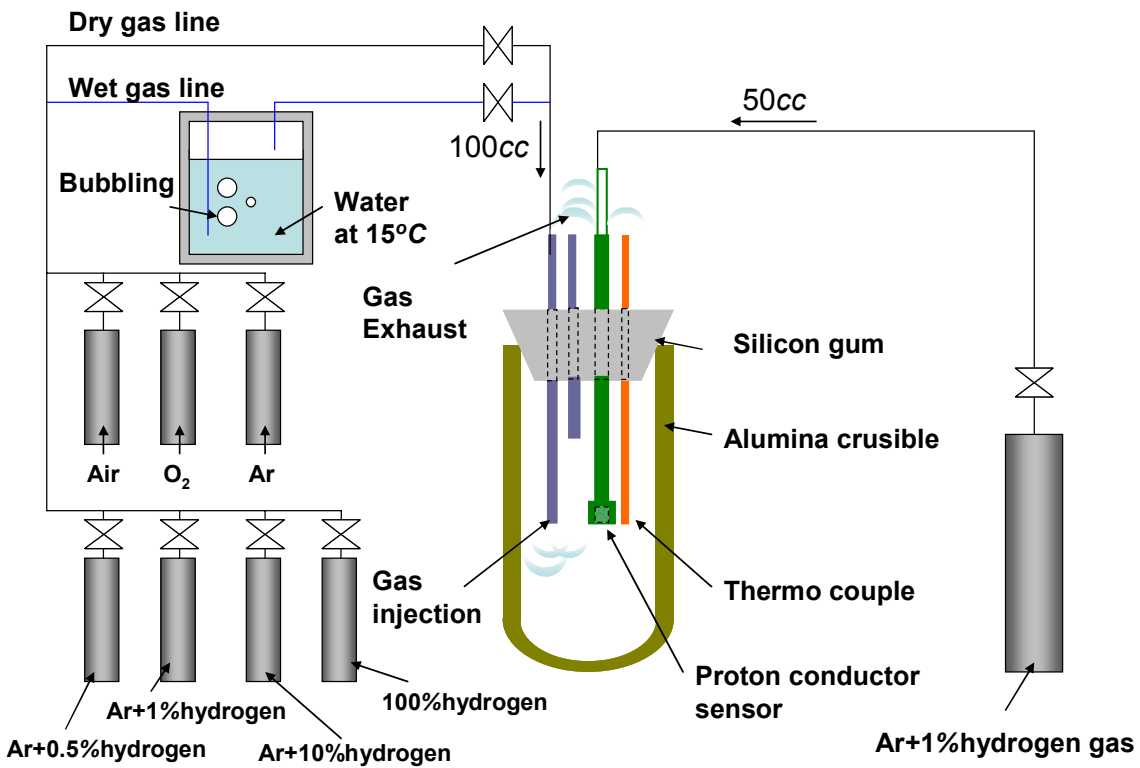

Fig. 3 Test apparatus for sensor performance test in gas atmosphere

Impedance measurement of the sensor was performed in gas atmosphere before a series of performance tests. In this work, the electro conductivity of sensor and the availability for hydrogen measurement were checked. Figure 4 shows impedance plots at $600^{\circ} \mathrm{C}$ in $\mathrm{Ar}+1 \% \mathrm{H}_{2}$ gas before the sensor performance test. The region at high frequency more than $2589 \mathrm{~Hz}$ showed the impedance of the $\mathrm{CaZr}_{0.9} \mathrm{In}_{0.1} \mathrm{O}_{3-\alpha}$ ceramics bulk. The impedance at the frequency of $2589 \mathrm{~Hz}$ is that of grain boundary in the $\mathrm{CaZr}_{0.9} \mathrm{In}_{0.1} \mathrm{O}_{3-\alpha}$ ceramics. The region at the frequency lower than $2589 \mathrm{~Hz}$ showed the impedance of the electrode. The impedance plots of the ceramic bulks and the electrode formed two semicircles. These 
semicircles indicated that the sensor is available for the hydrogen measurement. The measured impedance of this sensor at $600^{\circ} \mathrm{C}$ is $12293 \Omega$. This was sufficiently small compared with that of electrometer of $10^{9} \Omega$ for the hydrogen measurement.

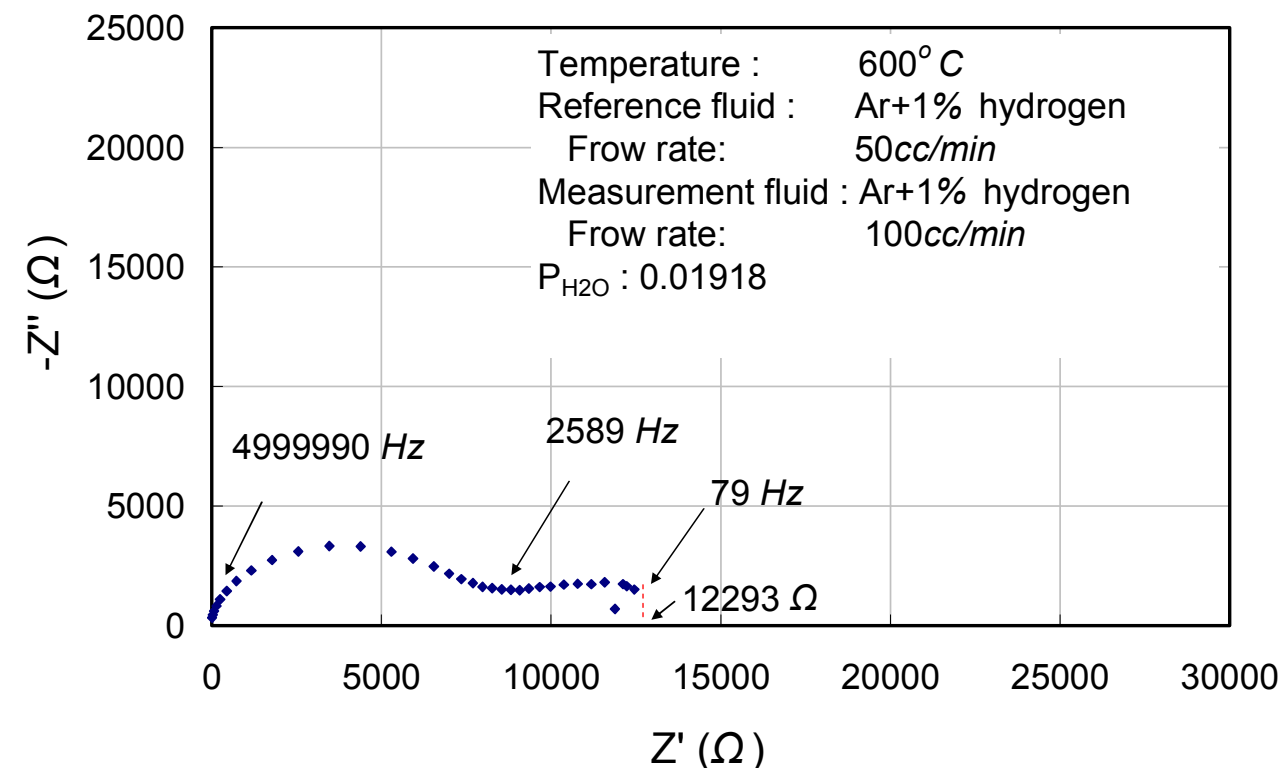

Fig. 4 Impedance plots of $\mathrm{CaZr}_{0.9} \mathrm{In}_{0.1} \mathrm{O}_{3-\alpha}$ sensor in $\mathrm{Ar}+1 \%$ hydrogen atmosphere before performance test

\subsection{Results of sensor performance test}

Figure 5 shows the results of the performance test at high hydrogen activity conditions. Blue solid line shows the EMF obtained from the sensor in the experiment, and red dotted line shows theoretical EMF calculated by using Eq. (4). It was found that the sensor output was agreed well with those of the theoretical calculation. The noise level error was detected shortly after the change of the hydrogen activity in gas atmosphere. This is because the gas, which was previously used, remained in the crucible and the hydrogen activity did not become constant.

The sensor showed the quick response as the EMF increase and decrease shortly after the change of hydrogen activity in the crucible. After the EMF became constant, the sensor kept the constant output in stable. In the test, good reproducibility was obtained at the same conditions.

Figure 6 shows the results of the test at low hydrogen activity conditions. Even at low hydrogen activity, the sensor output is consistent with those of the theoretical calculation. The good reproducibility was obtained at the same conditions.

The previous study implied that the oxygen could diffuse when there was the gradient of oxygen activity between the reference gas and the measurement liquid or gas at low temperature ${ }^{(13)}$. Thus, the effect of the oxygen on the sensor performance was investigated by means of the test with different oxygen condition at constant hydrogen activity. The oxygen activity in the gas atmosphere in the crucible was changed by the bubbling in the water. The tests were performed and compared by using the $\mathrm{Ar}-\mathrm{H}_{2}$ mixture dry gas and the wet gas which was obtained by the bubbling of the dry gases. The oxygen activity in the wet gases was much different from those of dry Ar- $\mathrm{H}_{2}$ gases because of the formation of $\mathrm{H}_{2} \mathrm{O}$. Table 2 shows that the effect of oxygen activity on the sensor performance was negligible. Therefore, it was found that the proton was predominant career in this measurement. 
Table 2 Effect of oxygen activity on sensor performance

\begin{tabular}{llll}
\hline \multicolumn{4}{l}{ Electro motive force $(\mathrm{mV})$} \\
\hline Hydrogen activity & Dry gas & Wet gas & Calculation \\
\hline 0.005 & -26.2 & -25.5 & -26.1 \\
\hline 0.01 & -3.54 & -1.87 & 0 \\
\hline 0.1 & 85.0 & 86.5 & 86.6 \\
\hline 1 & 171.2 & 173.0 & 173.2 \\
\hline
\end{tabular}

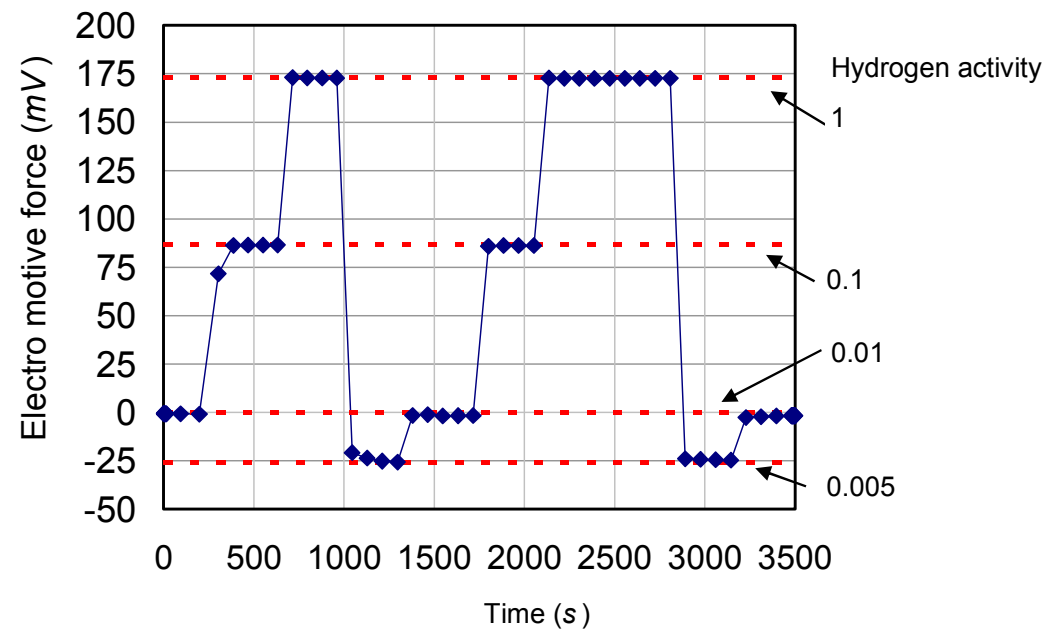

Fig. 5 Sensor performance in high hydrogen activity gas atmosphere at $600{ }^{\circ} \mathrm{C}$

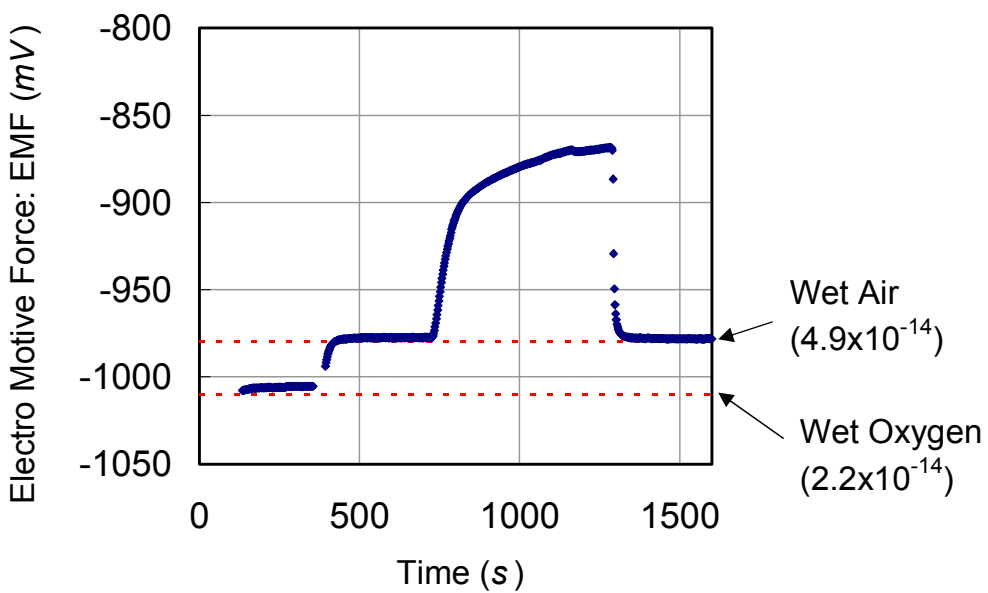

Fig. 6 Sensor performance in low hydrogen activity gas atmosphere at $600{ }^{\circ} \mathrm{C}$

\section{Conclusions}

The design study and performance test on on-line sensor for liquid metals and molten salt were carried out. Major conclusions are follows;

(1) The hydrogen sensor was designed based on calculated oxygen activity in liquid metals and molten salt. For the on-line measurement of hydrogen in liquid $\mathrm{Pb}$ and $\mathrm{Pb}$ alloy, the direct immersion type hydrogen sensor was designed. The sensor cell is directly immersed in the liquid. As for the measurement in liquid $\mathrm{Na}, \mathrm{Li}$ and Flibe, cap type sensor which has gas compartment is useful because the melt does not contact with 
sensing part and the sensing part is not reduced and corroded by the reducible melt.

(2) The performance tests for the In-doped $\mathrm{CaZrO}_{3}$ sensor in the gas atmosphere at $600{ }^{\circ} \mathrm{C}$ were carried out. In the test, the hydrogen activity in the gas varied from $2.2 \times 10^{-14}$ to 1 to simulate those in the liquid $\mathrm{Pb}, \mathrm{Pb}-\mathrm{Bi}, \mathrm{Pb}-17 \mathrm{Li}, \mathrm{Na}, \mathrm{Li}$ and Flibe. It was found that the sensor exhibited good response, stability and reproducibility. In the hydrogen measurement by using In-doped $\mathrm{CaZrO}_{3}$ sensor in the gas atmosphere at $600^{\circ} \mathrm{C}$, the oxygen activities in the gas did not affect on the sensor performance.

Acknowledgments

This study was supported by National Institute for Fusion Science budget code 2006UCFF002, Ministry of Education, Culture, Sports, Science and Technology KAKENHI 19760599 and The Sasakawa Scientific Research Grant from The Japan Science Society.

\section{References}

(1) Ueda, N., Kinoshita, I., Minato, A., Kasai, S., Yokoyama, T., and Maruyama, S., Progress in Nuclear Energy, vol.47, No. 1-4 (2005), pp. 222-230.

(2) Takahashi, M., et al., 2002, Proceedings. of ICONE10 (2002-4), ICONE10-22166 CD-ROM

(3) Muroga, T., Tanaka T., and Sagara A., Fusion Engineering and Design, vol. 81, (2006), pp. 1203-1209.

(4) Sagara, A., Tanaka, T., Muroga, T., Hashizume, H., Kunugi, T., Fukuda, S., Suzuki, A., et al., Fusion Engineering and Design, vol.49-50, (2000), pp. 661-666.

(5) Malang, S. and Mattas, R., Fusion Engineering and Design, vol. 27, (1995), pp. 399-406.

(6) Newman, R. N. and Smith C.A., Journal of Nuclear Materials, vol. 52, (1974), pp. 173-183.

(7) Kondo, M., Takahashi, M., Miura and K., Onizawa, T., Journal of Nuclear Materials, vol. 357, (2006), pp. 97-104.

(8) Kondo, M., Takahashi, M., Sawada, N., Hata, K., Journal of Nuclear Science and Technology, vol. 43, (2006), pp.107-116.

(9) Kondo, M., Takahashi, M., Miura, K., Onizawa, T., Journal of Nuclear Materials, vol. 343, (2004), pp. 349-359.

(10) Ricapito, I., Fazio, C., Benamati, G., Journal of Nuclear Materials, vol. 301, (2002), pp. 60-63.

(11) Kinoshita, M., Fukada, S., Yamashita, N., Muroga, T., Nishikawa, M., Fusion Engineering and Design, vol. 81, (2006), pp. 567-571.

(12) Yajima, T., Koide, K., Takai, H., Fukatsu, N. and Iwahara, H., Solid State Ionics, Vol. 79, (1995), pp. 333-357.

(13) Kurita, N., Fukats, N., Ito, K. and Ohashi, T., Journal of Electrochemical Society, vol. 142, (1995), pp.1552-1559.

(14) Gromov, B.F., Orlov, Y.I., Martynov, P.N., Gulevsky, V.A., Proceedings of HLMC1999, (1999), pp 87-100.

(15) Fukatsu, N., Kurita, N., Koide, K., Ohashi, T., Solid State Ionics, vol. 113-115, (1998), pp. 219-227.

(16) Gnanasekaran, T., Journal of Nuclear Materials, vol. 274, (1999), pp. 252-272.

(17) Moriyama, S., Tanaka, S., Sze, D.K., Reimann, J., Terlain, A., Fusion Engineering and Design, vol. 27, (1995), pp. 226-239.

(18) JSME Data Book : Heat Transfer $4^{\text {th }}$ Edition, (1986), pp. 323- 325, Maruzen corp.. 